\title{
Kedudukan Hukum Tentang Hak Istri Pegawai Negeri Sipil yang Diceraikan Berdasarkan Peraturan Pemerintah Nomor 10 Tahun 1983
}

\author{
Zaini Bidaya', Abrar² \\ ${ }^{1}$ Pendidikan Pancasila dan Kewarganegaraan, Universitas Muhammadiyah Mataram, Email: zainibidaya@gmail.com \\ ${ }^{2}$ Pendidikan Pancasila dan Kewarganegaraan, Universitas Muhammadiyah Mataram, Email: abrarian24@gmail.com
}

\begin{abstract}
INFO ARTIKEL
Riwayat Artikel:

Diterima: $\quad$ 13-

Februari-2019

Disetujui: 25-Maret2019
\end{abstract}

\section{Kata Kunci: \\ hukum \\ hak istri \\ PNS \\ diceraikan}

\begin{abstract}
ABSTRAK
Abstrak: Maraknya perceraian pegawai negeri sipil di Kota Bima membuat urgen untuk ditinjau berdasarkan PP nomor 10 Tahun 1983 jo PP nomor 45 tahun 1990 berkaitan dengan kedudukan dan hak istri setelah diceraikan oleh suami pegawai negeri sipil. Tujuan penelitian ini untuk mengetahui kedudukan hukum istri setelah diceraikan, dan untuk mengetahui hak-hak apa saja yang seharusnya didapatkan oleh istri setelah diceraikan oleh suami yang berstatus Pegawai Negeri Sipil. Penelitian ini menggunakan pendekatan kualitatif dengan metode deskriptif, objek dari penelitian ini adalah masyarakat yang melakukan perceraian dikalangan Pegawai Negeri Sipil di kota Bima. Pemilihan subyek dilakukan secara purposiv sampling dan snowball sampling. Pengumpulkan data dilakukan melalui wawancara, observasi, dan dokumentasi. Data dianalisis dengan cara mereduksi, menyajikan, dan menarik kesimpulan. Hasil penelitian menunjukkan bahwa ada beberapa faktor penyebab terjadinya perceraian yaitu; selingkuh, ketidak cocokan antar suami dan istri, kekerasan dalam berumah tangga. Kedudukan antara suami dan istri sudah jelas berdasarkan pasal 79 kompilasi hukum Islam di atas. Adapun hak-hak yang dipenuhi oleh suami setelah perceraian adalah; hak mut'ah (pemberian suami kepada istri berupa barang atau benda), nafkah lahir selama masa iddah, harta gono-gini, dan perawatan dan pendidikan anak. PNS ingin bercerai harus memenuhi syarat formal dan substansil.
\end{abstract}

\begin{abstract}
The rise of the divorce of civil servants in Bima City made urgent to be reviewed based on the PP Number 10 the year 1983 Jo PP number 45 the year 1990 relating to the position and right of the wife after being divorced by the husband of civil servants. The purpose of this research is to know the position of the wife's law after being divorced and to know what rights the wife should have gained after being divorced by a husband in the status of civil servants. This study used a qualitative approach with a descriptive method, the object of the study is a community that commits a divorce among civil servants in the city of Bima. The subject selection is performed purposive sampling and snowball sampling. Datasensing is done through interviews, observations, and documentation. Data is analyzed by reducing, presenting, and drawing conclusions. The results showed that there were several factors causing the divorce; Husband and wife, violence in a housekeeper. The position between husband and wife is clearly based on article 79 of the compilation of Islamic law above. The rights fulfilled by the husband after divorce are; Rights of Mut'ah (giving a husband to wife in the form of goods or objects), living birth during Iddah, Gono-Gini property, and child care and education. Civil servants wanting to divorce must meet formal requirements and substance.
\end{abstract}

\section{A. LATAR BELAKANG}

Telah ditegaskan dalam Undang-undang Nomor 1 Tahun 1974 bahwa putusnya perkawinan disebabkan oleh tiga faktor yaitu, kematian, perceraian dan karena putusan hakim. Dengan demikian perceraian merupakan salah satu faktor penyebab putusnya perkawinan. Dan perceraian hanya dapat dilakukan di depan sidang pengadilan setelah pengadilan yang bersangkutan berusaha dan tidak berhasil mendamaikan kedua belah pihak. Hal ini merupakan suatu kejadian yang menghilangkan suatu hak-hak dan kewajiban dalam hidup berumah tangga. Dengan adanya perceraian ini akan menimbulkan akibat hukum, baik terhadap suami ataupun istri yang ditinggalkan, anak maupun terhadap harta benda dalam perkawinan. Dari akibat hukum tersebut, maka yang sering menjadi persengkataan bagi para pihak adalah mengenai harta benda dalam perkawinan yang berwujud harta bersama [1].

Pegawai Negeri Sipil wajib memberikan contoh yang Dbaik bagi bawahannya dan menjadi teladan sebagai warga negara yang baik dalam masyarakat termasuk dalam menyelenggarakan kehidupan keluarga. Selanjutnya dalam penjelasan umum peraturan pemerintah tersebut disebutkan bahwa Pegawai Negeri Sipil adalah unsur aparatur negara, abdi negara dan abdi 
masyarakat yang harus menjadi teladan yang baik bagi masyarakat dalam tingkah laku, tindakan dan ketaatan kepada peraturan perundang-undangan yang berlaku untuk dapat melaksanakan kewajibannya [2]. Untuk dapat melaksanakan kewajiban yang demikian itu, maka kehidupan Pegawai Negeri Sipil (PNS) dalam melaksanakan tugasnya tidak akan banyak terganggu oleh masalah-masalah keluarga. Ketidakharmonisan kehidupan keluarga yang terus menerus bagi seorang Pegawai Negeri Sipil (PNS) akan sangat mengganggu tugas-tugas kedinasannya, oleh karena itu perceraian adalah hal yang mungkin dilakukan untuk mengatasi ketidakharmonisan tersebut. Namun disisi lain Pegawai Negeri Sipil juga terikat oleh PP 10 Tahun 1983 dan PP 45 Tahun 1990, yang tentunya tidak mudah bagi seorang PNS melaksanakan perceraian. Selain itu apabila seorang PNS telah dapat melewati rambu-rambu yang ada pada PP tersebut ia dapat melakukan perceraian [2]

Fakta yang terjadi dilapangan berdasarkan hasil pengamatan sementara secara empiris oleh peneliti bahwa banyak sekali terjadi kasus-kasus perceraian di Kota Bima yang begitu fenomenal didalam masyarakat. Beberapa kasus perceraian yang diamati oleh peneliti tersebut banyak sekali dan terdapat beberapa kalangan diantaranya termasuk Pegawai Negeri Sipil.

Salah satu dari beberapa kasus tersebut yang dilakukan oleh kalangan PNS yang pernah peneliti lakukan pengamatan yaitu terjadi di Kelurahan Raba Dompu-Kota Bima dengan latar belakang masalah bahwa pihak istri diceraikan oleh pihak suami yang berstatus Pegawai Negeri Sipil dengan alasan yang tidak terlalu prinsip untuk keduanya bercerai apalagi keduanya sama-sama berstatus PNS. Saat keduanya masih menjadi suami istri dalam kehidupannya seharihari keduanya sering terjadi percekcokan dan perselisihan dalam mengatur rumah tangga. Dalam hal ini tentu sangat tidak etis sekali bagi PNS yang menjadi tauladan bagi masyarakat untuk bercerai dengan alasanalasan yang tidak perlu untuk dibawa sampai ke jenjang perceraian dan sangat bertolak belakang dengan apa yang telah termuat dalam ketentuan umum PP No. 10 Tahun 1983 jo PP No 45 tahun 1990 tentang izin perkawinan dan perceraian bagi PNS bahwa, unsur aparatur negara, abdi negara dan abdi masyarakat yang harus menjadi teladan yang baik bagi masyarakat dalam tingkah laku, tindakan dan ketaatan kepada peraturan perundang-undangan yang berlaku untuk dapat melaksanakan kewajibannya. Untuk dapat melaksanakan kewajiban yang demikian itu, maka kehidupan Pegawai Negeri Sipil (PNS) dalam melaksanakan tugasnya tidak akan banyak terganggu oleh masalah-masalah keluarganya [3].

Dalam hal ini pihak istri selalu dibatasi dalam mengatur kehidupan rumah tangga mereka seperti masalah keuangan misalkan uang belanja anak dan istri sehari-hari yang seharusnya seorang istri yang mempunyai kewajiban dalam mengatur jalannya keharmonisan dalam kehidupan berumah tangga. Setelah terjadinya perceraian mantan istri tidak mendapatkan sebagian harta dari pihak mantan suaminya tersebut. Pada hal harta tersebut pada saat keduanya sebelum bercerai merupakan harta milik bersama.

Mantan istri menginginkan harta tersebut dibagikan namun mantan suami tidak menginginkan harta tersebut tidak dibagikan dengan alasan bahwa yang menjadi ahli warisnya adalah mantan suami dan harta tersebut yang menjadi hak waris adalah anakanaknya. Pihak mantan istri tetap menginginkan dan terus berupaya bagaimana harta tersebut tetap dibagikan.

Berdasarkan data perkara yang diperoleh peneliti bahwa terdapat tiga jenis perkara khusus PP No. 10 Tahun 1983 jo PP No. 45 tahun 1990 yaitu izin poligami, cerai talak, cerai gugat yang di mana ketiga perkara tersebut pada tahun 2010 terdapat 32 jumlah perkara mulai dari bulan Januari sampai bulan Desember 2010 yang masuk ke PA kelas IA Kota Bima. (Data Perkara Khusus PP No. 10 Tahun 1983 jo PP No. 45 Tahun 1990).

Direktur LBH APIK NTB Beauty Erawati menjelaskan "Kasus poligami yang dilaporkan sangat tinggi" ujarnya. Pada tahun 2005 dan 2006, masingmasing angkanya mencapai 529-an kasus. Pengaduan korban poligami 70 persen (melibatkan Pegawai Negeri Sipil (PNS) dan yang lainnya masalah nafkahnya NTB.

Fakta pendampingan mengatakan bahwa penyebab terbesar dari perceraian disebabkan karena adanya kasus kekerasan yang dialami istri, diantaranya adalah adanya kekerasan fisik seperti pemukulan, adanya kekerasan psikis seperti dikata-katai dan bahkan dituduh selingkuh.

Penelitian ini mengkaji tentang kedudukan Hukum Tentang Hak Istri PNS Setelah Diceraikan Berdasarkan PP No. 10 Tahun 1983 jo PP No 45 tahun 1990 di Kota Bima dan Hak-Hak apa saja yang didapatkan oleh istri setelah diceraikan oleh suami yang berstatus PNS serta Faktor-faktor penyebab terjadinya perceraian yang dilakukan oleh suami yang berstatus PNS. Adapun tujuan penelitian ini untuk mengetahui Faktor-faktor penyebab terjadinya perceraian yang dilakukan oleh suami yang berstatus PNS ditinjau dari PP No. 10 Tahun 1983 jo PP No 45 tahun 1990, untuk mengetahui kedudukan hukum tentang hak istri Pegawai Negeri sipil yang diceraikan ditinjau pada PP No. 10 Tahun 1983 bagi PNS, dan untuk mengetahui hak hak apa saja yang seharusnya didapatkan oleh istri setelah diceraikan suami yang berstatus PNS.

\section{B. METODE PENELITIAN}

\section{Metode Penelitian yang Digunakan}

Penelitian ini menggunakan pendekatan kualitatif dengan metode deskriptif. Pendekatan kualitatif merupakan penelitian yang bermaksud untuk memahami fenomena tentang apa yang dialami oleh 
subyek penelitian, misalnya perilaku, persepsi, tindakan dan lain-lain secara holistik dan dengan cara deskriptif dalam bentuk kata-kata dan bahasa pada suatu konteks khusus yang alamiah dan memanfaatkan metode alamiah [4].

Alasan peneliti menggunakan pendekatan kualitatif adalah untuk mencari tahu terkait kedudukan hukum tentang hak istri pegawai negeri sipil yang diceraikan, pendekatan kualitatif ini dapat digunakan untuk menemukan dan memahami apa yang tersembunyi dibalik fenomena yang kadangkala merupakan suatu yang sulit untuk diketahui dan dipahami [5]. Hal yang sejalan dengan tujuan penelitian yang menggunakan metode deskriptif yaitu, prosedur pemecahan masalah yang diselidiki dengan menggambarkan atau melukiskan keadaan obyek penelitian pada saat sekarang, berdasarkan fakta-fakta yang tampak atau sebagaimana adanya [6].

\section{Lokasi Penelitian}

Lokasi penelitian ini bertempat di Pengadilan Agama Kelas 1B Kelurahan Mpunda-Kota Bima. Adapun batas-batas lokasi penelitian adalah sebagai berikut; Sebelah timur berbatasan dengan Kantor Depag Kota Bima, sebelah selatan berbatasan dengan Kantor Departemen Sosial Kota Bima, sebelah barat berbatasan dengan Jalan Raya Mpunda, dan sebelah utara berbatasan dengan kantor Bupati Kabupaten Bima.

\section{Subjek Penelitian}

Dalam penelitian ini yang menjadi subyeknya adalah masyarakat yang diidentifikasi sebagai pelaku perceraian dengan istri atau suami yang berstatus PNS di Kota Bima. Pemilihan subyek dilakukan dengan cara purposive sampling, yaitu secara sengaja berdasarkan kriteria yang ditentukan dalam artian untuk menjaring informasi, peneliti memilih subyek terteliti berdasarkan lingkungan tempat tinggalnya masing-masing yang telah mengalami hal tersebut. Hal ini dilakukan secara tersebar artinya tidak berfokus pada satu tempat saja sehingga memungkinkan antara subyek yang satu dengan subyek yang lainnya tidak mengenal, hal itu dilakukan guna menghindari jawaban yang sama dari pertanyaan yang diajukan kepada subyek.

Dalam penelitian ini, penentuan informan akan dilakukan dengan teknik purposive sampling adalah teknik pengambilan sampel sumber data dengan pertimbangan tertentu. Pertimbangan tertentu ini, misalnya orang tersebut yang dianggap paling tahu tentang apa yang kita harapkan, atau mungkin dia sebagai penguasa sehingga akan memudahkan peneliti menjelajahi obyek/situasi yang diteliti.

Penelitian telah merencanakan A sebagai orang pertama sebagai sumber data. Informan awal ini sebaiknya dipilih orang yang bisa "membukakan pintu" untuk mengenali secara keseluruhan medan secara luas. Selanjutnya oleh A disarankan ke B dan C, dari C dan B belum memperoleh data yang akurat, maka peneliti ke $\mathrm{F}$ dan $\mathrm{G}$, dari $\mathrm{F}$ dan $\mathrm{G}$ belum memperoleh data yang akurat, maka peneliti pergi ke E, selanjutnya ke $\mathrm{H}$, ke G, ke I dan terakhir ke J. setelah sampai $J$ data sudah jenuh, sehingga sampel sumber data sudah mencukupi dan tidak perlu menambah sampel yang baru [7].

Berdasarkan gambar alur di atas dapat dijelaskan sebagai berikut. Penelitian telah mrencanakan informan 1 sebagai orang pertama sebagai sumber data. Informan awal ini sebaiknya dipilih orang yang bisa "membukakan pintu" untuk mengenali secara keseluruhan medan secara luas. Selanjutnya oleh informan 1 disarankan ke informan 2 dan informan 3. Dari informan 3 dan informan 2 belum memperoleh data yang akurat, maka berlanjut ke informan 4 dan informan 5 . Setelah sampai ke informan 5 data sudah jenuh, sehingga sampel sumber data sudah mencukupi, dan tidak perlu menambah sampel yang baru.

\section{Jenis dan Sumber Data}

\section{a) Jenis Data}

Adapun jenis data dalam hal ini dapat dibagi menjadi 2 (dua) kelompok yaitu.

1) Data Kuantitatif

Data yang dapat diukur nilainya secara langsung dengan cara memberi skor pada daftar pertanyaan atau kuesioner atau data yang berbentuk angka-angka.

2) Data Kualitatif

Data yang berbentuk kalimat, kata atau gambar atau data yang tidak dapat diukur nilainya secara langsung yang dinyatakan dalam bentuk tanggapan konsumen atau pernyataan seperti sangat positif, positif, negatif dan sangat negatif [8].

Adapun jenis data yang diambil dalam penelitian ini adalah data kualitatif untuk mengetahui kedudukan hukum tentang hak istri yang diceraikan dan untuk mengetahui hak-hak apa saja yang didapat ole istri setelah diceraikan oleh suami yang berstatus PNS berdasarkan PP No.10 Tahun 1983.

\section{b) Sumber Data}

Yang dimaksud dengan sumber data dalam penelitian ini adalah Subyek dari mana data diperoleh. Menurut [9] sumber data menurut sifatnya digolongkan menjadi 2 jenis yaitu sumber data primer dan sumber data sekunder.

1) Sumber data primer adalah sumber-sumber yang memberikan data langsung dari tangan pertama.

2) Sumber data sekunder adalah sumber mengutip dari sumber lain.

Data yang dipakai dalam penelitian ini adalah Data primer dan Data Sekunder. Jadi data primer adalah sumber data yang didapatkan melalui wawancara dan observasi. Sedangkan data sekunder 
adalah sumber data yang didapatkan melalui dokumentasi berupa foto, arsip, video.

\section{Metode Pengumpulan Data}

Teknik pengumpulan data yang digunakan dalam penelitian ini adalah.

\section{a) Observasi}

Observasi diartikan sebagai pengamatan atau pencatatan secara sistimatik mengenai tingkah laku dengan melihat mengamati individu atau kelompok secara langsung [10]. Metode ini digunakan untuk melihat dan mengamati secara langsung keadaan dilapangan agar peneliti memperoleh gmabaran yang lebih luas tentang permasalahan yang diteliti. Pengumpulan data dengan teknik ini dimaksudkan untuk mengantisipasi kekurangan-kekurangan yang ada atau tidak dapat diungkapkan dalam wawancara.

\section{b) Wawancara (Interview)}

Wawancara adalah percakapan dengan maksud tertentu oleh dua pihak, yaitu pewawancara (interviewer) sebagai pengaju/pemberi pertanyaan dan yang diwawancarai (interviewee) sebagai pemberi jawaban atas pertanyaan itu [10].

Pertanyaan dalam wawancara diajukan secara verbal yakni dilakukan dengan cara berhadapan langsung dengan subyek maupun informan penelitian. Sebelum melakukan wawancara peneliti membuat daftar pertanyaan yang akan ditanyakan kepada subyek maupun informan guna memudahkan melakukan wawancara.

Adapun wawancara dalam penelitian ini adalah wawancara berbeda atau tidak terstruktur yang bersifat luwes yaitu susunan pertanyaan yang dapat diubah pada saat wawancara dilakukan dan disesuaikan dengan kebutuhan situasi dan kondisi serta kemampuan peneliti sendiri [10].

\section{c) Dokumentasi}

Dokumentasi berasal dari asal kata " Dokumen " yang artinya barang barang tertulis. Didalam melaksanakan metode dokumentasi, peneliti menyelidiki benda benda tertulis seperti buku notulen rapat, catatan harian, arsip dan sebagainya [11]. Dokumen merupakan catatan peristiwa yang sudah berlalu. Dokumen bisa berbentuk tulisan, gambar, atau karya-karya misalnya catatan harian, sejarah kehidupan, ceritera, biografi, peraturan, kebijakan [8]. Metode dokumen yaitu mencari data mengenai hal-hal atau variabel yang berupa catatan, transkrip, buku, surat kabar, majalah, prasasti, notulen rapat, lengger, agenda, dan sebagainya [11].

Dari definisi para ahli di atas dapat diketahui bahwa tehnik dokumentasi adalah suatu tehnik penelitian yang ditujukan kepada pengurai dan penjelasan terhadap apa yang telah berlangsung melalui sumber-sumber dokumen dalam menggali suatu data.

Metode dokumentasi ini digunakan untuk meneliti dan mencatat peristiwa-peristiwa tentang gejala-gejala dilapangan saat proses penelitian berlangsung yang sesuai dengan data dokumentasi kantor Pengadilan Agama Kota Bima.

\section{Teknik Analisi Data}

Analisis data proses mengatur urutan data, mengorganisasikan ke dalam suatu pola, kategori dan satuan urusan dasar[4]. adalah. Proses analisis data dalam penelitian ini digunakan konstruksi tiga jalur; yaitu dengan reduksi data, penyajian data dan penarikan kesimpulan[8].

\section{1) Reduksi Data}

Proses pemilihan, pemusatan perhatian pada penyederhanaan, pengabstrakan, dan transformasi data kasar yang muncul dari catatan tertulis di lapangan, dalam hal ini catatan tertulis yang dimaksud adalah instrumen penelitian yang dibagikan kepada subyek penelitian. Reduksi data berlangsung terus menerus selama penelitian, sesudah penelitian lapangan sampai laporan akhir tersusun. Dengan kata lain reduksi data merupakan suatu bentuk analisis yang menajamkan, menggolongkan, mengarahkan, membuang yang tidak perlu dan mengorganisasikan data dengan cara sedemikian rupa sehingga kesimpulan finalnya dapat ditarik. Data yang diambil adalah tentang kedudukan hukum dan hak istri setelah perceraian dengan suami yang berstatus PNS di Kota Bima.

2) Penyajian Data

Tahap kedua dari kegiatan analisis data adalah penyajian data. Penyajian data adalah sekumpulan informasi menjadi konsep rasional sesuai dengan kenyataan sehingga memungkinkan menarik kesimpulan. Data-data yang telah diambil dan telah direduksi akan disajikan secara deskripsi dimana hasil wawancara diubah bahasanya menjadi kalimat yang lebih baku dan mudah dimengerti serta dikaitkan dengan teori-teori sesuai dengan hasil wawancara dan observasi.

3) Menarik kesimpulan atau verifikasi

Kegiatan analisis data yang ketiga adalah menarik kesimpulan. Penarikan kesimpulan dilakukan dalam bentuk memuat kesimpulan hasil penelitian yang dituangkan dalam bentuk pembahasan. Dalam alur ini merupakan kegiatan untuk mengambil kesimpulan terhadap hasil penelitian yang telah dilakukan atau proses penarikan kesimpulan akhir dari data yang telah diambil.

\section{HASIL DAN PEMBAHASAN}

\section{Faktor penyebab terjadinya perceraian yang dilakukan oleh Suami berstatus PNS di Kota Bima}

Pengertian perceraian menurut Undang-Undang No. 1 Tahun 1974 tentang perkawinan, perceraian adalah putusan ikatan perkawinan yang telah dilaksanakan menurut ketentuan Undang-Undang [12]. Jadi perceraian adalah putusnya hubungan 
perkawinan antara suami istri, dimana menyebabkan hubungannya telah atau tidak dapat dilanjutkan dalam melaksanakan kehidupan rumah tangga. Perceraian dapat terjadi apabila ada ucapan atau kata-kata talak oleh sang suami kepada istrinya dan yang terakhir mendapat putusan dari pengadilan agama terkait sah atau tidaknya sebuah perceraian.

Berdasarkan data perkara yang diperoleh peneliti bahwa terdapat tiga jenis perkara khusus PP No. 10 Tahun 1983 jo PP No. 45 tahun 1990 yaitu izin poligami, cerai talak, cerai gugat yang dimana ketiga perkara tersebut pada tahun 2010 terdapat 60 jumlah perkara mulai dari bulan Januari sampai bulan Desember 2010 yang masuk dan telah diputuskan oleh PA kelas IB Kota Bima. (Data Perkara Khusus PP No. 10 Tahun 1983 jo PP No. 45 Tahun 1990).

Data Perkara Khusus PP. No Tahun 1983 jo. PP No. 45 Tahun 1990 Pada PA Kelas lB Bima 2010.

Tabel 1

Laporan khusus PP No. 10 Tahun 1983 jo PP No. 45 Tahun 1990 PA kelas lB Kota Bima 2010.

\begin{tabular}{|c|c|c|c|c|}
\hline \multirow[b]{2}{*}{ Bulan } & \multicolumn{3}{|c|}{$\begin{array}{c}\text { JenisPerkaraTahun } \\
2010\end{array}$} & \multirow[b]{2}{*}{ Ket } \\
\hline & $\begin{array}{c}\text { Izin } \\
\text { polig } \\
\text { ami }\end{array}$ & $\begin{array}{l}\text { Cerai } \\
\text { talak }\end{array}$ & $\begin{array}{l}\text { Cerai } \\
\text { gugat }\end{array}$ & \\
\hline Januari & - & 0 & 1 & \\
\hline Februari & - & 2 & 7 & \\
\hline Maret & - & 6 & 2 & \\
\hline April & - & 2 & 0 & \\
\hline Mei & - & 2 & 0 & \\
\hline Juni & - & 4 & 2 & \\
\hline JUli & - & 5 & 2 & \\
\hline Agustus & - & 3 & 2 & \\
\hline September & - & 2 & 1 & \\
\hline Oktober & - & 6 & 3 & \\
\hline November & - & 0 & 4 & \\
\hline Desember & - & 1 & 5 & \\
\hline Jumlah & - & 31 & 29 & $\begin{array}{c}\text { Total=60 } \\
\text { Perkara yang } \\
\text { telah } \\
\text { diputuskan } \\
\text { Oleh PA Kota } \\
\text { Bima }\end{array}$ \\
\hline
\end{tabular}

Dasar hukum perceraian bagi PNS.

1. Peraturan Pemerintah Nomor 10 Tahun 1983 jo Peraturan Pemerintah Nomor 45 Tahun 1990 tentang Izin Perkawinan dan Perceraian Bagi Pegawai Negeri Sipil.

2. Surat Edaran Badan Administrasi Kepegawaian Negara Nomor 08/SE/1983 dan Nomor 48/SE/1990 tentang Petunjuk Pelaksanaan Peraturan Pemerintah Nomor 45 Tahun 1990 jo Peraturan Pemerintah Nomor 10 Tahun 1983 Tentang Izin Perkawinan dan Perceraian Bagi Pegawai Negeri Sipil
Dari data hasil penelitian yang dilakukan, diperoleh data bahwa Faktor penyebab terjadinya perceraian yangdilakukan oleh PNS di Kota Bima adalah Suami berselingkuh dengan wanita lain, Tidak ada kecocokan dengan suami, Suami sering bertindak kasar dan memaki-maki istri dengan kata-kata yang kasar dan Dibohongi dan dikhianati oleh suami yang mengaku masih bujangan. Seperti yang diungkapkan oleh subyek penelitian sebagai berikut:

"Yang melatar belakangi terjadinya perceraian dalam rumah tangga kami adalah karena tidak ada kecocokan dengan suaminya dan seringnya suami saya bertindak kasar dan suka memaki saya dengan kata-kata yang sangat kasar" (Fatun Fatimah; 17 Desember 2011)

Dari apa yang diungkapkan oleh subyek diatas bahwa, subyek tersebut tidak tahan dan tidak kuat lagi terhadap perlakuan suaminya dan merupakan alasan subyek untuk bercerai dengan suaminya.

Di hari dan tempat tinggal yang berbeda subyek mungungkapkan sebagai berikut.

"Yang melatar belakangi terjadinya perceraian adalah mantan suami saya berselingkuh dengan wanita lain yang dulunya mantan pacarnya sebelum dia menikah dengan saya dan mengakibatkan wanita yang diselingkuhinnya tersebut hamil dari itu saya melakukan gugatan cerai ke pengadilan" (Ana Susilawati; 18 Desember 2011).

Dari apa yang diungkapkan oleh subyek diatas bahwa, subyek merasa sangat kecewa dan terpukul sekali terhadap apa yang dilakukan oleh suaminya tersebut sehingga subyek melakukan gugatan cerai kepada suaminya di pengadilan Agama.

Kebanyakan dari subyek yang melakukan perceraian mengungkapkan bahwa mereka tidak diberlakukan secara adil sebagai seorang istrinya dalam kehidupan berumah tangga yang seharunya saling melindungi dan saling menopang satu sama lainnya.

2. Kedudukan Hukum Istri Setelah Dicerai-kan Oleh Suami yang Berstatus PNS

Kedudukan suami-istri menurut Pasal 79 Kompilasi Hukum Islam, antara lain:

1. suami adalah kepala keluarga dan istri adalah ibu rumah tangga;

2. hak dan kedudukan istri adalah seimbang dengan hak dan kedudukan suami dalam kehidupan rumah tangga dan pergaulan hidup bersama dalam masyarakat;

3. masing-masing pihak berhak untuk melakukan perbuatan hukum.

Akibat hukum yang lain adalah masalah harta benda dalam perkawinan yang terdapat dalam Bab XIII Kompilasi Hukum Islam, Pasal 86 menjelaskan, bahwa: 
1. pada dasarnya tidak ada percampuran antara harta suami dan harta istrikarena perkawinan;

2. harta istri tetap menjadi hak istri dan dikuasai sepenuhnya olehnya, demikian juga harta suami tetap menjadi hak suami dan dikuasai sepenuhnya olehnya.

Terkait kedudukan antara suami dan istri berdasarkan pasal 79 kompilasi hukum Islam di atas dapat dikatakan bahwa, kedudukannya terhadap hukum sudah jelas namun pada prakteknya banyak yang belum tahu akan hal seperti itu, namun yang terpenting bagi mereka adalah tidak merugikan salah satu pihak. Seperti yang diungkapkan oleh subyek penelitian sebagai berikut.

"Terkait dengan kedudukan saya di dalam hukum saya tidak begitu tahu!! Bagi saya yang terpenting adalah terbaik untuk saya dan anak-anak saya nantinya" (Suhada Binti Mansyur; 16 Desember 2011).

Dari apa yang diungkapkan oleh subyek penelitian di atas bahwa, subyek tersebut belum mengerti terkait dengan kedudukanya di dalam hukum, namun yang terpenting bagi subyek adalah yang terbaik untuk dirinya terlebih lagi untuk anakanaknya kelak.

Demikian halnya dengan yang disampaikan oleh subyek penelitian di bawah ini: "Saya tidak begitu tahu akan kedudukan saya di dalam hukum mas!! Yang penting bagi saya tidak ada yang dirugikan” (Ana Susilawati, SE; 18 Desember 2011)

Dari pernyataan subyek penelitian tersebut di atas bahwa, subyek tahu sedikit pengetahuan terkait kedudukannya di dalam hukum, jadi untuk pastinya subyek belum tahu sama sekali.

Kebanyakan dari subyek yang melakukan perceraian belum tahu pasti terkait kedudukannya didalam hukum. Mereka juga tidak mempermasalahkan terkait kedudukannya, namun yang jelas bagi mereka adalah hukum tersebut akan berlaku adil terhadap mereka. Hal ini seperti yang disampaikan oleh subyek penelitian:

"Nah kalau ditanyakan kedudukan saya di dalam hukum, saya belum mengerti. Namun yang pasti hukum dalam perceraian tersebut sangat penting adanya" (Fatun Fatimah ; 17 Desember 2011)

Menurut penuturan subyek tersebut di atas, subyek sadar akan pentingnya kedudukan dihadapan hukum, mereka berpikir bahwa kedudukannya di dalam hukum cukup mempengaruhi terkait dengan hak-haknya. Hal ini seperti yang disampaikan oleh subyek penelitian yaitu:

"Kedudukan saya di dalam hukum cukup berpengaruh terhadap pemenuhan hak-hak saya mas!! Alasannya karena hukum yang menentukan segalanya, yang pastinya hukum tersebut akan bertindak secara adil"
(Mislikah Laily Purnama Sari, S.Hi ; 14 Desember 2011)

Kebanyakan dari subyek yang melakukan perceraian mengungkapkan bahwa kedudukannya di dalam hukum cukup berpengaruh terhadap pemenuhan hak-haknya oleh mantan suaminya.

3. Hak Istri Setelah Diceraikan Oleh Suami yang Berstatus PNS Berdasar PP No. 10 Tahun 1983 jo PP No. 45 Tahun 1990

Setiap warga negara hendaknya melaksanakan setiap peraturan yang telah ditetapkan oleh pemerintah, sebab semua peraturan pada hakikatnya bertujuan untuk kepentingan masyarakat demikian juga dalam halnya perceraian. Sedangkan yang dimaksud dengan perceraian menurut UndangUndang No. 1 tahun 1974 tentang perkawinan, perceraian adalah putusan ikatan perkawinan yang telah dilaksanakan menurut ketentuan UndangUndang [12].

Dari hasil penelitian yang dilakukan oleh peneliti pada masyarakat Kota Bima, ada beberapa hak yang dipenuhi oleh seorang suami kepada mantan istri dan anak-anak diantaranya adalah:

Hak mut'ah adalah pemberian suami kepada mantan istri setelah bercerai baikberupa barang atau benda. Hak mut'ah wajib diberikan bekas suami jika perceraian itu kehendak suami. Yang menjadi landasan hukum adanya mut'ah ini adalah surat AlBaqarah ayat 241 yang artinya: "Kepada wanitawanita yang diceraikan (hendaklah diberikan oleh suaminya) mut'ah menurut yang ma'ruf, sebagai suatu kewajiban bagi orang-orang yang bertakwa”.

Secara zhahir, ayat di atas sesungguhnya menghendaki suami wajibmemberi mut'ah, yaitu pemberian secara sukarela, disamping nafkah kepada istri yang diceraikannya.

Dari data hasil penelitian yang dilakukan, diperoleh data bahwa kebanyakan dari pihak istri yang tidak mendapatkan hak mut'ah tersebut. Sebagaimana yang dinyatakan oleh subyek penelitian:

"Yang melatar belakangi sehingga terjadi perceraian antara dirinya dengan suaminya adalah bermula dari KDRT dan suami suka berjudi dan mabuk-mabukan. saking tidak tahannya saya menggugat cerai terhadap suami saya. Terkait dengan hak mut'ah saya tidak dapat!! Kalau untuk saya pribadi, dia hanya memberikan 50.0oo tiap bulanya buat anaknya saja. Dari pada saya dibentak lebih baik saya diam diri saja. Tapi untungnya saya pegawai, jadi saya bisa menanggung semua biaya kebutuhan anak saya" (Suhada Binti Mansyur ; 16 Desember 2011)

Dari apa yang diungkapkan oleh subyek penelitian di atas hak mut'ah tidak sepenuhnya dipenuhi oleh mantan suami terhadap mantan istrinya. Demikian halnya dengan yang disampaikan oleh subyek penelitian dibawah ini: 
"Terkait dengan hak mut'ah dari mantan suami saya, sampai sekarang tidak saya dapatkan, hahkan semenjak perceraian tersebut terjadi mantan suami saya tidak menampakan wajahnya lagi sedangkan untuk perawatan dan pendidikan anak saya tanggung sendiri" (Fatun Fatimah ; 17 Desember 2011).

Dari apa yang diungkapkan oleh subyek penelitian di atas bahwa hak mut'ah tidak didapatkannya dari mantan suami dan bahkan semenjak perceraian itu terjadi mantan suami tidak pernah terlihat lagi.

Sementara tentang jumlah mut'ah yang harus diberikan itu, dijelaskan dalam surat Al-Baqarah ayat 236. Ayat tersebut tidak menyebutkan batasan maksimal dan minimal mut'ah yang harus diberikan suami kepada istrinya. Sepertinya ayat ini memberikan hak sepenuhnya kepada suami dalam menentukan jumlah pemberian itu. Satu-satunya syarat yang diberikan ayat ini adalah "kepatutan". Hal itu terlihat dari pernyataan yang menyebutkan bahwa "Orangyang mampu menurut kemampuannya dan orang yang miskin menurut kemampuannya (pula), yaitu pemberian menurut yang patut". Dengan pernyatan seperti ini, maka ada tiga unsur kepatutan yang mesti diperhatikan dalam pemberian mut'ah. Pertama, kepatutan atau kepantasan berdasarkan kemampuan si suami, dan itu didasarkan pada ayat di atas. Artinya, suami yang kaya tidak pantas memberikan mut'ah yang sama jumlahnya dengan suami yangtermasuk golongan miskin, dan sebaliknya. Kedua, patut atau pantas bagi si istri. Artinya, istri yang terbiasa dengan pola hidup "cukup" atau (apalagi) "mewah" dengan suami itu atau keluarganya sebelumnya, tidak pantas kalau mendapat mut'ah yang jumlahnya "sedikit". Sebabnya, seperti dikatakan al-Kasaniy, karena mut'ah itu sendiri adalah sebagai ganti dari "kemaluannya". Oleh karena itu, keadaan si istrilah yang jadi pedoman dalam penentuan mut'ah itu. Ketiga, patut atau pantas menurut adat yang berlaku di lingkungan tempat mereka hidup. Hal ini perlu mendapatkan perhatian, setidaknya, untuk menghindari terjadinya kesenjangan sosial antara si istri yang diberi mut'ah dengan orang-orang yang berada di sekitarnya.

Nafkah iddah, adalah nafkah yang diberikan pada masa iddah. Iddah menurut bahasa artinya menghitung. Sedangkan menurut syara' adalah masa menunggubagi seorang istri selama waktu tertentu setelah terjadi thalaq atau ditinggal meninggal oleh suami. Dasar hukum iddah yang mengacu pada hukum naqli guna memperjelas tentang iddah itu sendiri. Dasar dari Al Qur'an;

wanita-wanita yang ditalak hendaklah menahan diri (menunggu) tiga kali quru. Tidak boleh mereka menyembunyikan apa yang diciptakan
Allah dalam rahimnya, jika mereka beriman kepada Allah dan hari akhirat. Dan suamisuaminya berhak merujukinya dalam masa menanti itu, jika mereka (para suami) itu menghendaki ishlah. Dan para wanita mempunyai hak yang seimbang dengan kewajibannya menurut cara yang ma'ruf. Akantetapi para suami mempunyai satu tingkatan kelebihan dari pada istrinya. Dan Allah Maha Perkasa lagi Maha Bijaksana (QS. Al Baqarah: 228).

Ayat di atas walaupun sebenarnya telah di nasakh oleh ayat yang kemudian, akan tetapi kandungan dari hukum ayat tersebut tetaplah dipakai dan dipergunakan sebagai dalil hukum dalam penetapan hukum Islam syara' yang berkenaan dengan masalah iddah istri. Ayat yang demikian ini dalam istilah ilmu ulumul qur'an disebut dengan baqouttilawah wa hukmi adamul. Dasar dari Hadits; Hadits dari Bukhari dan Muslim yang artinya:

Dari Abu Mas'ud Al Badry ra. Dari Nabi SAW. Beliau bersabda "Apabila seseorang menafkahkan harta untuk keperluan keluarga, hanya berharap dapat memperoleh pahala maka hal itu akan dicatat sebagai sedekah baginya.

Undang-undang No. 1 tahun 1974 tentang perkawinan menetapkan waktu tunggu bagi seorang wanita yang putus perkawinan. Selanjutnya atas dasar pasal 11 Undang-undang No. 1 tahun 1974 tentang perkawinan ditetapkan waktu tunggu sebagai berikut: Ayat (1) Bagi seorang wanita yang putus perkawinannya berlaku jangka waktu tunggu. (2) Tenggang waktu jangka waktu tunggu tersebut ayat satu akan diatur dalam peraturan pemerintah lebih lanjut.

Dari data hasil penelitian yang dilakukan oleh peneliti, diperoleh databahwa dari 5 subyek penelitian, ada 3 subyek yang tidak mendapatkan nafkah lahir pada masa iddah. Sebagaimana yang dinyatakan oleh subyek penelitian:

"Saya tidak mendapatkan nafkah lahir pada masa iddah saya, pokoknya suami saya tidak mau tahu!! Malah saya pernah ke rumanya untuk minta uang untuk keperluan anak, tapi saya tidak mendapatkan respon apapun dari mantansuami saya, jadi saya malas untuk minta bantuan sama mantan suami saya lagi. Hal tersebut terjadi berawal pada waktu itu saya pergi untuk mencari anak saya di rumah orang tua, anak saya tersebut kerumah neneknya karena diusir oleh bapak angkatnya.

Hingga akhirnya saya dibilang istri yang tidak patuh terhadap perintahnya" (Fatun Fatimah ; 17 Desember 2011).

Dari apa yang diungkapkan oleh subyek penelitian di atas bahwa nafkah lahir selama masa iddahtidak diperolehnya dari mantan suami bahkan untuk meminta bantuan saja dari pihak suami enggan menanggapinya. Hal tersebut terjadi berawal pada waktu itu subyek pergi untuk mencari anaknya dirumah orang tuanya, anak subyek tersebut 
kerumah neneknya karena diusir oleh bapak angkatnya. Hingga akhirnya subyek dibilang istri yang tidak patuh terhadap perintahnya.

Demikian halnya dengan yang disampaikan oleh subyek penelitian di bawah ini:

"Nafkah lahir selama masa iddah tidak saya dapatkan dari mantan suami!! Alasannya setelah perceraian dengan saya, ternyata suami saya sudah menikah lagi dengan wanita dari kempo, jadi apa yang bisa saya dapatkan dari perkawinan saya, yang ada cuma sengsara saja. Hal tersebut terjadi karena mantan suami saya banyak hutang, sehingga rumah saja sudah kamijual untuk melunasinya." (Mislikah Laily Purnama Sari, S,Hi ; 14 Desember 2011)

Dari apa yang diungkapkan oleh subyek penelitian di atas bahwa nafkah lahir selama masa iddah tidak diperolehnya dari mantan suami bahkan setelah perceraian terjadi dengan subyek, mantan suami tersebut menikah lagi. Hal tersebut terjadi karena mantan suami subyek banyak hutang, sehingga rumah yang dibangunnya mereka jual untuk melunasinya.

\section{TEMUAN DAN DISKUSI}

Hak dan kewajiban suami istri selama iddah. Para ulama mazhab sepakat bahwa istri yang beriddah dari talak raj'i wajib memperoleh nafkah dan tempat tinggal, dan istri juga wajib menjalani iddahnya di rumah suaminya, begitu juga dengan wanita yang hamil dan suami berkewajiban memenuhinya. Hal ini sesuai dengan firman Allah yang Artinya: Tempatkanlah mereka (para istri) dimana kamu bertempat tinggal menurut kemampuan danjanganlah kamu menyusahkan mereka untuk menyempitkan (hati) mereka. Dan jika mereka (istri-istri yang sudah ditalak) itu sedang hamil, maka berikanlah kepada mereka nafkah hingga mereka melahirkan kandungannya (QS. AthThalaq : 6)

Jika seorang istri itu berada dalam masa iddah karena ditinggal mati suaminya, maka istri tersebut wajib berkabung atas kematian suaminya dengan meninggalkan pemakaian perhiasan dan wangiwangian, istri juga wajib tinggal di rumah suaminya, artinya dia wajib menghabiskan masa iddahnya di rumah suaminya, dia tidak boleh keluar rumah dengan berlebihan, kecuali ada keperluan. Namun ulama mazhab berbeda pendapat mengenai nafkah dan tempat tinggal bagi istri yang ditalak ba'in. Istri yang ditalak ba'in. Apabila seorang istri itu hamil, maka suami wajib menyediakan tempat tinggal dan nafkah untuknya. Namun apabila seorang istri yang ditalak ba'in itu tidak hamil, menurut Imam Hanafi ia juga berhak mendapat nafkah dari suaminya. Tetapi menurut imam Hambali tidak wajib baginya nafkah. Sedangkan menurut imam Malik dan Syafi'i wajib untuknya tempat tinggal, namun tidak wajib untuknya nafkah.

Dari data hasil penelitian yang dilakukan oleh peneliti, diperoleh data bahwa ada beberapa subyek yang tidak mendapatkan harta bersama (gono-gini). Sebagaimana yang dinyatakan oleh subyek penelitian sebagai berikut.

"Terkait harta gono-gini, saya tidak mendapatkan dari mantan suami saya. Alasanya karena saya tidak memiliki anak hasil perkawinan dengan suami saya"(Rafa'ah binti H.Ahmad ; 15 Desember 2011)

Dari apa yang diungkapkan oleh subyek penelitian di atas bahwa terkait dengan harta gonogini subyek tersebut tidak mendapatkannya, suaminya tersebut beralasan bahwa tidak ada anak hasil perkawinan dengan subyek.

Hal tersebut senada dengan yang disampaikan oleh subyek penelitianyang lain yaitu:

"Saya tidak dapat harta gono-gini dari suami saya mas!!, alasannya karena saya bukan lagi istrinya dan juga katanya kesalahan saya yang tidak patuhterhadap perintahnya. Katanya harta tersebut buat anaknya saja sedangkan anak dari hasilperkawinan dengan almarhum suami saya tidak diperhatikan" (Suhada Binti Mansyur ; 16 Desember 2011).

Dari apa yang diungkapkan oleh subyek penelitian di atas bahwa terkait dengan harta gonogini subyek tersebut tidak mendapatkannya dari mantan suaminya, suaminya tersebut beralasan bahwa tidak ada harta gono-gini untuk mantan istrinya, karna harta tersebut untuk keperluan anaknya dari hasil perkawinan dengan almarhum istrinya.

Sedangkan menurut syara' tidak membagi harta gono-gini ini dengan bagian masing-masing secara pasti (fixed, tsahii), misalnya istri 50\% dan suami50\%. Sebab tidak ada nash yang mewajibkan demikian, baik dari Al-Qur'an maupun As-Sunnah. Namun pembagiannya bergantung pada kesepakatan antara suami dan istri berdasarkan musyawarah atas dasar saling ridha. Inilah yang disebut dengan ashshulhu (perdamaian) diantara suami istri.

Dengan demikian, berdasarkan dalil hadits 'Amr bin 'Auf Al-Muzni ra di atas, jika suami istri bercerai dan hendak membagi harta gono-gini diantara mereka, dapat ditempuh jalan perdamaian (ashshulhu). Sebab salah satu jenis perdamaian adalah perdamaian antar suami istri (ash-shulhu baina azzaujain), atau perdamaian tatkala ada persengketaan mengenai harta bersama (amlaak). Dengan jalan perdamaian ini, pembagian harta gono-gini bergantung pada musyawarah antara suami istri. Boleh suami mendapat 50\% dan istri 50\%. Boleh suami mendapat 30\% dan istri $70 \%$, boleh pula suami mendapat $70 \%$ dan istri $30 \%$, dan boleh pula 
pembagian dengan nisbah (persentase) yang lain. Semuanya dibenarkan syara' selama merupakan hasil dari perdamaian yang telah ditempuh berdasarkan kerelaan masing-masing.

Perawatan dan pendidikan anak, kewajiban suami untuk membiayai anak-anak yang belum mencapai umur 21 (dua puluh satu) tahun.

Masalah suami yang tidak mau memberikan nafkah pada keluarga banyak terjadi disebagian masyarakat kita. Bagi istri atau ibu yang tidak mempunyai penghasilan, hal ini tentu sangat memberatkan karena harus menanggung biaya perawatan dan pendidikan anak-anaknya. Secara normatif, hukum di Indonesia, khususnya mengenai hak nafkah bagi istri dan anak, baik dalam masa perkawinan maupun setelah perceraian, dapat dikatakan sudah cukup melindungi kepentingan perempuan. Pasal 34 ayat 1 [12] tentang Perkawinan, menyatakan bahwa: Suami wajib melindungi istrinya dan memberikan segala keperluan hidup berumah tangga sesuai dengan kemampuannya. Ini berarti bahwa suami berkewajiban penuh memberikan nafkah bagi keluarganya (anak dan istri). Ketentuan ini merupakan konsekuensi dari ketentuan yang menetapkan suami sebagai kepala keluarga dan istri sebagai ibu rumahtangga serta pengurus rumah tangga sebagaimana yang ditentukan oleh Pasal 31 ayat 3. Sebenarnya, bila kita tilik lebih jauh, pembagian peran seperti ini akan menimbulkan ketergantungan secara ekonomi bagi pihak perempuan (istri). Akibat lebih jauhnya, perempuan (istri) tidak memiliki "akses ekonomi" yang sama dengan suami dimana istri tidak memiliki kekuatan untuk memaksa suami memberikan nafkah yang cukup untuk keluarganya. Sehingga seringkali suami memberi nafkah sesuka hatinya.

Apabila perceraian terjadi atas kehendak bersama suami istri, maka pembagian gaji diatur dalam PP No. 10 Tahun 1983 jo PP No. 45 Tahun 1990 sebagai berikut:

1) Apabila perkawinan tidak menghasilkan anak, maka pembagian gaji berdasarkan kesepakatan bersama.

2) Dengan tidak mengurangi ketentuan di atas, apabila semua anak mengikuti bekas istri, maka 1/3 gaji untuk anak dan diterimakan pada istri.

3) Apabila sebagian anak mengikuti PNS yang bersangkutan dan sebagian mengikuti bekas istri maka 1/3 gaji dibagi jumlah anak (sebagian ikut istri/suami).

SANKSI: PNS dijatuhi salah satu hukuman disiplin berat berdasarkan Peraturan Pemerintah Nomor 30 Tahun 1980 (sekarang Peraturan Pemerintah Nomor 53 Tahun 2010) bila:

1) Melakukan perceraian tanpa memperoleh izin dari Pejabat bagi yang berkedudukan sebagai
Penggugat atau tanpa surat keterangan bagi yang berkedudukan sebagai Tergugat, terlebih dahulu dari Pejabat.

2) Apabila menolak melaksanakan pembagian gaji dan atau tidak mau menandatangani daftar gajinya sebagai akibat perceraian

3) Tidak melaporkan perceraiannya kepada Pejabat dalam jangka waktu selambat-lambatnya satu bulan setelah terjadinya perceraian.

4) Setiap atasan yang tidak memberikan pertimbangan dan tidak meneruskan pemintaan izin atau pemberitahuan adanya gugatan perceraian untuk melakukan perceraian, dan atau untuk beristri lebih dari seorang dalam jangka waktu selambat-lambatnya 3 (tiga) bulan setelah ia menerima permintaan izin atau pemberitahuan adanya gugatan perceraian.

5) Pejabat yang tidak memberikan keputusan terhadap permintaan izin perceraian atau tidak memberikan surat keterangan atas pemberitahuan adanya gugatan perceraian, dan atau tidak memberikan keputusan terhadap permintaan izin untuk beristri lebih dari seorang dalam jangka waktu selambat-lambatnya 3 (tiga) bulan setelah ia menerima izin atau pemberitahuan adanya gugatan perceraian.

Dalam PP tersebut sudah sangat jelas, namun dalam prakteknya masih ada saja yang belum melaksanakan kewajibannya terhadap mantan istrinya. Hak yang sebenarnya yang harus didapat oleh seorang istri terhadap suami sesuai PP tersebut, tetapi tetap saja tidak diperolehnya.

Dari hasil penelitian yang dilakukan, diperoleh data bahwa ada saja darisubyek yang belum mendapatkan nafkah terkait kebutuhan dan pendidikan anak. Sebagaimana yang dinyatakan oleh subyek penelitian sebagai berikut.

"Yang membiayai sekolah anak saya adalah orang tua saya mas!! Kalau dari saya belum ada, saya hanya lulusan SMA dan saya sebagai ibu rumah tangga aja. Sedangkan neneknya tukang jahit pakaian jadi untuk biaya sekolahnya sudah cukup. Kebutuhan sekolah anak-anak saya, seperti pembelian seragam sekolah, tas, buku dll, merupakan tanggungan saya sendiri dan orang tua saya sedangkan pas perceraian tersebut terjadi mantan suami saya sudah lepas tangan.Saya tidak mendapatkan hak terkait untuk perawatan anak-anak dari mantan suami saya seperti yang saya bilang tadi, mantan suami saya sudah lepas tangan buat ngurusin anak saya" (Fatun Fatimah ; 17 Desember 2011).

Dari apa yang diungkapkan oleh subyek penelitian di atas bahwa terkait dengan perawatan dan pendidikan anak tidak subyek dapatkan, mantan suaminya tersebut semenjak perceraian terjadi sudah 
lepas tangan dan seakan-akantidak mau tahu akan masalah yang dihadapi oleh subyek.

Hal tersebut senada dengan apa yang disampaikan oleh subyek penelitian yang lain yaitu sebagai berikut:

"Yang membiayai sekolah anak saya adalah saya sendiri mas!! Kebutuhan sekolah anakanaksaya, seperti pembelian seragam sekolah, tas, buku dll, merupakan tanggungan saya sendiri. Sedangkan terkait hak untuk perawatan anak tidak ada sama sekali dari suami saya dan saya tidak butuh lagi sama dia biar semua keperluan anak saya, saya tanggung sendiri, syukurnya anak hasil perkawinan dengan mantan suami saya cuman satu orang" (Ana Susilawati, SE ; 18 Desember 2011).

Dari apa yang diungkapkan oleh subyek penelitian di atas bahwa terkait dengan perawatan dan pendidikan anak tidak subyek dapatkan, mantan suaminya tersebut semenjak perceraian terjadi menghilang dan tidak tahu kabarnya sampai sekarang oleh subyek.

Menurut Pasal 41 Undang-Undang No.1 Tahun 1974 menjelaskan akibat putusnya suatu perkawinan karena perceraian adalah sebagai berikut:

1) Baik ibu ataupun bapak tetap berkewajiban memelihara dan mendidik anak-anaknya, semata-mata berdasarkan kepentingan anakanak tersebut. Bilamana terjadi perselisihan yang menyangkut anak-anak ini, pihak Pengadilan yang akan menyelesaikannya atas permohonan pihak-pihak.

2) Bapak bertanggung jawab atas semua biaya pemeliharaan dan pendidikan yang diperlukan oleh anak. Jika dalam kenyataannya bapak tidak mampu, Pengadilan dapat menetapkan ibu yang bertanggung jawab memikul beban tersebut.

3) Pengadilan dapat diwajibkan suami untuk memberikan nafkah kepada atau menentukan suatu kewajiban bagi bekas istri.

Berdasarkan [13] menyatakan bahwa orang tua berkewajiban untuk mendidik anaknya, setelah perceraian terjadi pihak suami bertanggung jawab atas semua biaya pemeliharaan dan pendidikan anak dan apabila dalam pelaksanaannya terbukti bahwa pihak suami tidak mampu untuk membiayai pemeliharaan dan pendidikan anak maka pengadilan dapat menetapkan istri yang bertanggungjawab memikul beban tersebut. Pihak pengadilan dapat mewajibkan suami atau istri untuk membiayai pemeliharaan dan pendidikan anak.

Sedangkan hak istri yang tercantum dalam [2] dalam Pasal (8) Ayat (1-7) adalah sebagai berikut.

Ayat (1):

Apabila perceraian terjadi atas kehendak Pegawai Negeri Sipil pria maka iawajib menyerahkan sebagian gajinya untuk penghidupan bekas istri dan anak-anaknya.
Ayat (2):

Pembagian gaji sebagaimana yang dimaksudkan dalam ayat (1) ialah sepertiga untuk Pegawai Negeri Sipil pria yang bersangkutan, sepertiga untuk bekasistrinya dan sepertiga untuk anak atau anak-anaknya.

Ayat (3):

Apabila dari perkawinan tarsebut tidak ada anak maka bagian gaji yang wajib diserahkan oleh Pegawai Negeri Sipil pria kepada bekas istrinya ialah setengah dari gajinya.

Ayat (4):

Pembagian gaji kepada bekas istri tidak diberikan apabila alasan perceraian disebabkan karena istri berzinah, dan atau istri melakukan kekejaman atau penganiayaan berat baik lahir maupun batin terhadap suami, dan atau istri menjadi pemabuk, pemandat, dan penjudi yang sukar disembuhkan, dan atauistri telah meninggalkan suami selama dua tahun berturut-turut tanpa izin suami dan tanpa alasan yang sah atau karena hal lain di luar kemampuannya

Ayat (5):

Apabila perceraian terjadi atas kehendak istri, maka ia tidak berhak atas pembagian penghasilan dari bekas suaminya.

Ayat (6):

Ketentuan sebagaimana yang dimaksud dalam ayat (5) tidak berlaku, apabila istri meminta cerai karena dimadu, dan atau suami berzinah, dan atau suami melakukan kekejaman atau penganiayaan berat baik lahir maupun batin terhadap istri, dan atau suami menjadi pemabuk, pemandat, dan penjudi yang sukar disembuhkan, dan atau suami telah meninggalkan suami selama dua tahun berturut-turut tanpa izin istri dan tanpa alasan yang sah atau karena hal lain diluar kemampuannya

Ayat (7):

Apabila bekas istri Pegawai Negeri Sipil yang bersangkutan kawin lagi, maka haknya atas bagian gaji dari bekas suaminya menjadi terhapus terhitung ia kawin lagi.

Dari data hasil penelitian yang dilakukan, diperoleh data bahwa daripihak pengadilan tidak menjatuhkan berapa besar yang didapatkan oleh istri darisuaminya, sedangkan berdasarkan bunyi pasal 8 Ayat (2):

"Pembagian gaji sebagaimana yang dimaksudkan dalam ayat (1) ialah sepertiga untuk Pegawai Negeri Sipil pria yang bersangkutan, sepertiga untuk bekas istrinya dan sepertiga untuk anak atau anak-anaknya“.

Namun pada prakteknya yang berhak menentukan dapat atau tidak seorang istri terkait hak dari suaminya adalah atasan atau pejabat dari instansi tempat suaminya bekerja, hal ini sesuai yang diungkapkan oleh informan penelitian yaitu:

"Kedudukan hukum antara suami dan istri sama saja, terkait dengan hak istri selama perkawinan pihak pengadilan tidak berhak untuk menentukan berapa besar yang harus diterima tapi yang berhak adalah kepala atau 
pejabat suami dari tempat suami bekerja" (Mukhtar, SH: 20 Desember 2011).

Hal tersebut senada dengan yang disampaikan oleh informan penelitian yang lain yaitu:

"Kedudukan hukum antara suami dan istri sama saja, panmud hukum 2 menambahkan terkait dengan hak istri selama perkawinan pihak pengadilan tidak menentukan besar kecilnya yang didapat oleh istri setelah diceraikan oleh suami, tapi yang lebih berhak adalah kepala atau pejabat dari suami itu sendiri hal ini tercantum pada amar putusan (hukum terapan kita (PA) Kota Bima). Seorang pejabat juga menentukan berdasarkan jenis permasalahan yang dihadapi oleh bawahannya, dan bahkan seorang pejabat berhak untuk memberikan dan tidak terkait hak yang didapat oleh seorang istri” (Abubakar, SH.MH: 20 Desember 2011).

Dari apa yang diungkapkan oleh 2 informan penelitian di atas dapat disimpulkan bahwa pengadilan agama tidak menentukan besar kecilnya yang didapat oleh istri setelah diceraikan oleh suami, tapi yang lebih berhak menentukannya adalah kepala atau pejabat dari tempat suami berkerja, hal ini tercantum pada amar putusan (hukum terapan kita PA Kota Bima). Dan bahkan seorang pejabat berhak untuk tidak memberikan terkait hak yang didapat oleh seorang istri dengan mempertimbangkan permasalahan yang dihadapi.

Putusnya perkawinan karena perceraian hanya dapat dilakukan didepan sidang pengadilan, setelah pengadilan yang bersangkutan berusaha dan tidak berhasil mendamaikan kedua belah pihak.

Selanjutnya yang dimaksud dengan Pengadilan, yaitu.

1. Pengadilan Agama bagi mereka yang beragama Islam;

2. Pengadilan Negeri bagi mereka yang beragama selain Islam.

Mengenai proses perceraian untuk pasangan suami istri baik yang salah satunya PNS maupun keduanya bekerja sebagai seorang PNS (Pegawai Negeri Sipil) tidaklah semudah proses perceraian untuk pasangan suami istri yang bukan PNS. Hal ini disebabkan karena seorang PNS merupakan abdi masyarakat yang terikat kerja dengan pemerintah, sehingga seorang PNS harus menjadi panutan bagi masyarakat, sehingga perceraian bagi seorang PNS merupakan hal yang sulit untuk dilaksanakan. Mengenai perkawinan dan perceraian bagi PNS diatur dalam PP No.10 Tahun 1983. Prosedur perceraian bagi PNS harus berdasarkan pada PP No. 10 Tahun 1983 tersebut. Salah satu prosedur yang harus dilakukan adalah dengan meminta izin dari kepala tempat mereka bekerja. Izin yang diberikan tersebut harus berupa izin secara tertulis. Mengenai izin ini sesuai dengan Pasal 3 ayat (1) [3]yang meyebutkan "Pegawai Negeri Sipil yang akan melakukan perceraian wajib memperoleh izin lebih dahulu dari pejabat”. Dengan adanya persyaratan tersebut tampak bahwa penceraian bagiPNS khususnya merupakan hal yang sangat sulit dilakukan karena tanpa adanya surat izin dari kepalanya PNS tersebut tidak dapat melakukan penceraian.Yang menjadi permasalahan sekarang yaitu jika pasangan suami istri tersebut memang sudah tidak bisa hidup dalam satu perkawinan tetapi belum mendapat surat izin dari kepalanyadan pihak Pengadilan Agama tidak bisa melakukan penceraian. Dipersulitnya proses perceraian bagi PNS ini sematamata bukan hanya PNS sebagai panutan saja, tapi ada faktor-faktor lain yang menjadi pertimbangan kepala PNS yang bersangkutan sehingga proses perceraian bagi PNS tampak lebih sulit. Salah satunya akibat yang ditimbulkan dari perceraian tersebut adalah pengalihan sebagian gaji PNS kepihak istri sebagai kewajiban pemberian nafkah setelali perceraian. Tentu saja untuk melakukan pengalihan sebagaian gaji tersebut tidaklah mudah karena membutuhkan waktu dan prosedur yang panjang. Hal ini pula yang menjadi salah satu pertimbangan bagi seorang kepala PNS apabila akan memberi izin untuk bercerai bagi anak buahnya. Melihat begitu berpengaruhnya PNS menjadi panutan bagi masyarakat yang pada akhirnya menjadi suri tauladan bagi mereka tentunya seorang PNS harus memberikan contoh yang baik bagi masyarakat dalam kehidupan rumah tangga mereka sehingga hal tersebut akan berdampak positif bagi masyarakat itu sendiri.

Table 2

Gambaran pemahaman subyek penilitian mengenai Kedudukannya Dalam Hukum dan Hak Istri Setelah Perceraian Dengan Suami yang Berstatus PNS di Bima.

\begin{tabular}{|c|c|c|c|}
\hline No & $\begin{array}{c}\text { Subyek } \\
\text { dan Informan } \\
\text { Penilitian }\end{array}$ & $\begin{array}{l}\text { Kedudukann } \\
\text { ya di dalam } \\
\text { Hukum }\end{array}$ & $\begin{array}{c}\text { Hak Istri Setelah } \\
\text { Diceraikan Suami yang } \\
\text { Berstatus PNS }\end{array}$ \\
\hline 1 & $\begin{array}{c}\text { SPOl } \\
\text { (Suhada } \\
\text { Binti } \\
\text { Mansyur) }\end{array}$ & $\begin{array}{l}\text { Kurang lebih } \\
\text { tahu sedikit } \\
\text { tentang } \\
\text { hukum } \\
\text { perceraian. }\end{array}$ & $\begin{array}{l}\text { Tidak memperoleh hak } \\
\text { harta gono-gini, hak } \\
\text { iddah, hak mut'ah serta } \\
\text { biaya perawatan dan } \\
\text { pendidikan anak dari } \\
\text { mantan suami. }\end{array}$ \\
\hline 2 & $\begin{array}{c}\text { SP02 } \\
\text { (Mislikah } \\
\text { Laily } \\
\text { Purnama } \\
\text { Sari, SHi) }\end{array}$ & $\begin{array}{l}\text { Sedikit tahu } \\
\text { perihal } \\
\text { kedudukann } \\
\text { ya di dalam } \\
\text { hukum }\end{array}$ & $\begin{array}{l}\text { Mendapatkan haknya } \\
\text { darimantan suami seperti } \\
\text { hak } m u t^{\prime} a h \text {, hak iddah } \\
\text { dan harta gono-gini. } \\
\text { Perawatan dan } \\
\text { pendidikan anak } \\
\text { tanggungan subyek dan } \\
\text { mantan suami. }\end{array}$ \\
\hline
\end{tabular}




\begin{tabular}{|c|c|c|c|}
\hline 3 & $\begin{array}{c}\text { SP03 } \\
\text { (Ana } \\
\text { Susilawati,SE } \\
\text { ) }\end{array}$ & $\begin{array}{l}\text { Belum tahu } \\
\text { pasti terkait } \\
\text { kedudukann } \\
\text { ya di dalam } \\
\text { hukum }\end{array}$ & $\begin{array}{l}\text { Mendapatkan haknya } \\
\text { darimantan suami seperti } \\
\text { hak mut'ah, hak iddah } \\
\text { dan harta gono-gini. } \\
\text { Perawatan dan } \\
\text { pendidikan anak } \\
\text { tanggungan subyek } \\
\text { sendiri. }\end{array}$ \\
\hline 4 & $\begin{array}{c}\text { SP04 } \\
\text { (Rafa'ah } \\
\text { Binti } \\
\text { H.Ahmad) }\end{array}$ & $\begin{array}{l}\text { Tidak tahu } \\
\text { kedudukann } \\
\text { ya } \\
\text { di dalam } \\
\text { hukum }\end{array}$ & $\begin{array}{l}\text { Mendapatkan haknya } \\
\text { dari } \\
\text { mantan suami seperti hak } \\
\text { mut'ah, hak iddah, } \\
\text { hartagono-gini dan hak } \\
\text { perawatandan } \\
\text { pendidikan } \\
\text { anakmerupakan } \\
\text { tanggungan } \\
\text { berdua antara subyek } \\
\text { danmantan suami. }\end{array}$ \\
\hline 5 & $\begin{array}{c}\text { SP05 } \\
\text { (Fatun } \\
\text { Fatimah Binti } \\
\text { Umar) }\end{array}$ & $\begin{array}{l}\text { Belum } \\
\text { begitu } \\
\text { mengerti } \\
\text { kedudukann } \\
\text { ya di dalam } \\
\text { hukum }\end{array}$ & $\begin{array}{l}\text { Hanya mendapatkan } \\
\text { hartagono-gini. } \\
\text { Sedangkan hakmut'ah. } \\
\text { Hak iddah tidaksubyek } \\
\text { dapatkan, } \\
\text { sedangkanperawatan dan } \\
\text { pendidikan anak } \\
\text { tanggungan } \\
\text { subyeksendiri. }\end{array}$ \\
\hline
\end{tabular}

Sumber: Hasil wawancara dan observasi terhadap subyek

\section{E. SIMPULAN DAN SARAN}

Hasil penelitian menunjukkan bahwa faktor-faktor penyebab terjadinya perceraian yang dilakuakn oleh suami berstatus PNS di Kota Bima adalah 1). suami berselingkuh dengan wanita lain, 2). Tidak ada lagi kecocokan dengan suami, 3) suami sering bertindak kasar dan memaki-maki istri dengan kata-kata yang kasar, dan 3). dibohongi dan dikhianati oleh suami yang mengaku masih bujangan.

Terkait kedudukan antara suami dan istri berdasarkan pasal 79 kompilasi hukum Islam menjelaskan bahwa suami adalah kepala keluarga dan istri adalah ibu rumah tangga, hak dan kedudukan istri adalah seimbang dengan hak dan kedudukan suami dalam kehidupan rumah tangga dan pergaulan hidup bersama dalam masyarakat, masing-masing pihak berhak untuk melakukan perbuatan hukum. Dapat dikatakan bahwa, kedudukannya terhadap hukum sudah jelas namun pada pelaksanaannya masih ada yang belum tahu akan hal seperiti itu, namun yang terpenting bagi mereka adalah tidak merugikan salah satu pihak.

Ada beberapa hak yang dipenuhi oleh seorang suami kepada mantan istri dan anak-anak diantaranya adalah: Hak mut'ah wajib diberikan bekas suami jika perceraian itu kehendak suami. Apabila perceraian atas kehendak PNS pria maka ia wajib menyerahkan sebagian gajinya untuk penghidupan bekas istri dan anaknya, sistim pembagiannya yaitu sepertiga untuk PNS pria, sepertiga untuk bekas istri dan sepertiganya lagi untuk anak-anaknya. Apabila dari perkawinan tersebut tidak ada anak hasil perkawinan maka istri wajib mendapatkan setengah dari gaji mantan suaminya. Pembagian gaji kepada bekas istri tidak diberikan apabila alasan perceraian disebabkan karena istri berzinah, dan atau istri mlakukan kekejaman atau penganiayaan berat baik lahir maupun batin terhadap suami, dan atau istri menjadi pemabuk, pemadat dan penjudi yang sukar disembuhkan, dan atau istri telah meninggalkan suami selama dua tahun berturut-turut tanpa izin suami dan tanpa alasan yang sah atau karena hal lain di luar kemampuannya. Apabila bekas istri Pegawai Negeri Sipil yang bersangkutan kawin lagi, maka haknya atas bagian gaji dari bekas suaminya menjadi terhapus terhitung ia kawin lagi.

Ada dua syarat yang menjadi dasar bagi seorang PNS untuk melakukan perceraian yaitu syarat alternatif dan syarat kumulatif [14]. Namun pada kenyataan dilapangan yang ditemukan oleh peneliti bahwa kedua syarat tersebut tidak pakai oleh subyek penelitian untuk menjadi dasar perceraian karena faktor penyebab terjadinya perceraian tersebut atas dasar perlakuan suami kepada istri bukan atas dasar kedua syarat tersebut.

Ada beberapa hal yang akan disarankan untuk lebih meningkatkan kesadaran masyarakat khususnya bagi Pegawai Negeri Sipil yang akan bercerai, sebagai berikut.

a) Untuk Badan Kepegawaian Daerah (BKD) Kota Bima

Tingkat kesadaran masyarakat khususnya bagi PNS masih kurang terkait kedudukannya di dalam hukum setelah perceraian terlebih-lebih kedudukan hukum bagi istri setelah diceraikan oleh suami yang berstatus PNS, maka sangat diperlukan kegiatan penyuluhan hukum yang intensif tentang arti pentingnya terkait kedudukannya di dalam hukum setelah perceraian.

b) Untuk Para Pegawai Negeri Sipil (PNS)

Perceraian yang terjadi oleh kalangan PNS pria jangan sampai melupakan terkait hak dan kewajiban yang harus dipenuhinya dan berprilaku adil terhadap mantan istri dan anak-anaknya.

\section{UCAPAN TERIMA KASIH}

Penulis mengucapkan terima kasih kepada Universitas Muhammadiyah Mataram yang senantiasa memberikan dukungan materi dan Kantor Depag Kota Bima kepada penulis sehingga artikel ilimiah ini selesai dengan baik.

\section{DAFTAR RUJUKAN}

[1] W. Prodjodikoro, Hukum Perkawinan di Indonesia. Sumur Bandung, 1966.

[2] M. Machfudz, "Prinsip kesetaraan gender dalam PP. No. 10 Tahun 1983 Jo. PP. No. 45 Tahun 1990 Pasal 4 Ayat (2) tentang larangan dipoligami bagi PNS wanita." Universitas Islam Negeri Maulana 
Malik Ibrahim, 2014.

[3] R. Indonesia, "Peraturan Pemerintah RI, No. 10 tahun 1983 tentang Izin Perkawinan dan Perceraian bagi Pegawai Negeri Sipil.” dalam Himpunan Peraturan Perundangundangan Perkawinan.” Jakarta, 1983.

[4] L. J. Moleong, Metode Penelitian Kualitatif. Bandung: Remaja Rosdakarya, 2007.

[5] R. Bogdan and S. J. Taylor, Introduction to qualitative research methods: $A$ phenomenological approach to the social sciences. John Wiley \& Sons, 1975.

[6] H. Nawawi, "Metode Penelitian Bidang Sosial. (cetakan ke-13)," Gajah mada Univ. Press. Yogyakarta, hal, vol. 176, 2012.

[7] Sugiyono, "Memahami Penelitian Kualitatif," Bandung Alf., 2005.

[8] Sugiyono, "Metode Penelitian kuantitatif kualitatif dan R dan D," Alf. Bandung, 2010.

[9] S. Winarno, "Pengantar Penelitian Ilmiah Metode dan Teknik," Bandung: Tarsito, 2008.

[10] B. D. Suwandi and M. Si, "Memahami Penelitian Kualitatif Jakarta: PT," Reneka Cipta, 2008.

[11] A. Suharsimi, "Prosedur Penelitian Suatu Pendekatan Praktik," Jakarta: Rineka Cipta, 2006.

[12] U.-U. Nomor, "tahun 1974 tentang Perkawinan." $1 \mathrm{AD}$.

[13] B. A. Saebani, Perkawinan dalam hukum Islam dan undang-undang: perspektif fiqh munakahat dan UU no. 1/1974 tentang poligami dan problematikanya. Pustaka Setia, 2008.

[14] I. Purwaningsih, "Kedudukan Hukum Tentang Hak Istri Sebagai Pegawai Negeri Sipil Setelah Diceraikan Oleh Suami Yang Berstatus Pegawai Negeri Sipil Didasarkan Atas Peraturan Pemerintah No. 10 Tahun 1983," Kedudukan Huk. Tentang Hak Istri Sebagai Pegawai Negeri Sipil Setelah Diceraikan Oleh Suami Yang Berstatus Pegawai Negeri Sipil Didasarkan Atas Peratur. Pemerintah No. 10 Tahun 1983, 2014. 